\section{Couplings of Enzymes onto Microorganisms}

THE coupling of enzymes onto insoluble support materials offers several advantages including increased stabilization of the enzyme, re-use of the enzyme without tedious recovery by precipitation, and close control of the extent of conversion in enzyme reactors. Coupling may also afford an improved heat-stability, greater specificity, or a different $p \mathrm{H}$ optimum compared with the enzyme in the free state. On the whole, work on insolubilized enzymes has been confined to single enzymes separated from the organism that produced them and coupled to non-living supports ${ }^{1-4}$. The work reported here concerns the coupling of enzymes onto living cells in order to supplement the array of enzymes naturally produced.

It is well known that yeast cells secrete a number of enzymes including invertase, phosphatase and proteinase that become coupled naturally either by entrapment or covalent linkage to the mannan of the cell wall ${ }^{5}$. If cereal flour is added to a medium in which yeast is growing, $\beta$-amylase present in the flour and not native to the yeast is readily adsorbed onto the surface of the yeast cell walls ${ }^{6}$. In this case, the adsorption is insufficiently strong to prevent some of the enzyme being washed off subsequently and covalent linkage would therefore be preferred.

Insolubilization of enzymes by covalent linking has involved methods that are rather drastic for living organisms so that it is highly unlikely that they would remain viable if used as supports. A technique has been developed by Novais for covalent coupling using titanium salts ${ }^{7}$. Although in its original form it is too harsh, a modification provides more gentle treatment. Principally, the modifications have entailed lowering the concentration of the titanium salts, raising the $p \mathrm{H}$ levels during treatment and avoiding steps where the cells would desiccate.

In a typical treatment, $1.2 \mathrm{~g}$ of washed pressed brewery yeast with no amyloglucosidase (glucamylase) activity was stirred for $15 \mathrm{~min}$ at ambient temperature in titanic chloride $(0.125 \% \mathrm{w} / \mathrm{v})$ and then washed thrice in sodium acetate buffer at $p \mathrm{H} 4.5$. It was held overnight at $4^{\circ} \mathrm{C}$ in the presence of amyloglucosidase before repeated washings in the buffer and saline. The enzyme was covalently bound because the washings failed to bring it into solution and because the yeast displayed amyloglucosidase activity.

The activity of the yeast was measured as $\mathrm{mg}$ glucose released per min by $1 \mathrm{~g}$ dry weight of yeast from $1 \% \mathrm{Merck}$ soluble starch in $0.005 \mathrm{M}$ sodium acetate buffer at $p \mathrm{H} 4.5$, the assay being carried out at $45^{\circ} \mathrm{C}$. The glucose was measured after removal of yeast and free amino-acids by the NelsonSomogyi method. Typically, activities were in the range 5.3-8.3 after due allowance for blank values and the viable counts were in the range $50-80 \%$ as indicated by slide-culture procedures $^{8}$. This is illustrated in Table 1.

Table I Effect of Using Titanic Chloride for coupling Amyloglucosidase to Brewers' Yeast

\begin{tabular}{lccc}
\hline \multicolumn{1}{c}{ Treatment } & $p \mathrm{H}$ & $\begin{array}{c}\text { Viability } \\
\text { (slide } \\
\text { culture) }\end{array}$ & $\begin{array}{c}\text { Enzyme activity } \\
\text { (my glucose } \mathrm{g}^{-1} \\
\text { dry wt }\end{array}$ \\
None & 4.5 & 95 & 0 \\
Enzyme preparation in water only & \\
$2.5 \% \mathrm{TiCl}_{4}$ added only & 4.5 & 60 & 0 \\
$0.125 \% \mathrm{TiCl}_{4}$ added only & 1.0 & 10 & 0 \\
$2.5 \% \mathrm{TiCl}_{4}$ and enzyme used & 2.2 & 55 & 0 \\
$0.125 \% \mathrm{TiCl}_{4}$ and enzyme used & 1.0 & 10 & 17.1 \\
$2.0 \% \mathrm{TiCl}_{3}$ and enzyme used & 1.2 & 60 & 1.5 \\
\hline
\end{tabular}

Treatment consisted of three washings in $0.005 \mathrm{M}$ acetate buffer ( $\mathrm{H} 4.5$ ) stirred at $4^{\circ} \mathrm{C}$ with enzyme solution overnight (activity of the solution is $5.43 \mathrm{mg}$ glucose $\mathrm{mg}^{-1}$ protein $\mathrm{min}^{-1}$ ) and then washed four times alternately in acetate buffer and in acetate buffer plus $M$ sodium chloride, followed by four additional washings in acetate buffer. Results represent mean of three estimations.
A range of inorganic salts can be used as coupling agents with varying degrees of efficiency, including titanous, stannous and ferrous salts. Several strains of Saccharomyces cerevisiae have been employed successfully including strains 1004, 1005, 1026 and 1040 of the National Collection of Yeast Cultures, Brewing Industry Research Foundation, Nutfield, Surrey. A range of enzymes including bacterial a-amylase and trypsin have been coupled. Furthermore, amyloglucosidase has been successfully coupled on to Bacillus subtilis and Escherichia coli.

The coupling of amyloglucosidase to yeast permits hydrolysis of dextrins to yield simple sugars that the yeast can assimilate and ferment. Such a procedure would have value in the production of beer, vinegar, whisky or industrial ethanol. Other possible uses for enzymes coupled to yeast include the breakdown of protein in a medium if proteinase is coupled. This means that hazes involving protein ${ }^{9}$ could be removed by yeast. At the same time, the presence of yeast would maintain a low redox potential that is valuable in beverages such as beer. The simple treatment of yeast or bacteria as described could be used to augment their array of hydrolytic enzymes and provide a means of degrading a wider range of components in complex media. It also affords the opportunity of removing enzymes at a selected juncture, merely by centrifuging, filtering or precipitating the microorganisms.

When microorganisms that have been coupled multiply, the average enzyme activity of the individual cells will fall because of denaturation and because the new cells will not receive the coupled enzyme. In closed continuous fermenters, however, cell multiplication is low $^{10}$ and therefore the overall enzyme activity is likely to be maintained. The technique of coupling enzymes to living supports is in its infancy but could well be of wide application. It is envisaged that comparatively inexpensive enzymes will be used in many applications. The coupling procedure is simple, cheap and rapid so that the microorganisms can be coupled with fresh enzyme as required.

J. S. Hough

T. P. LYONS

Sub-Department of Malting and Brewing,

Department of Biochemistry,

University of Birmingham

Received April 28, 1971.

1 Silman, I. H., and Katchalski, E., Ann. Rev. Biochem., 873 (1966).

2 Barker, S. A., Somers, P. J., Epton, R., and McLaren, J. V., Carbohydrate Res., 14, 287 (1970).

3 Axen, R., Porath, J., and Ernback, S., Nature, 214, 1302 (1967).

4 Weetall, H. H., Biochim. Biophys. Acta, 212, 1 (1970).

5 Lampen, J. O., Anton van Leeuwenhoek, 34, 1 (1968).

6 Hopkins, R. H., Proc. Eur. Brew. Conv. Baden-Baden Congress, 315 (1955)

Barker, S. A., Emery, A. N., and Novais, J. M., Process Biochem., $6(10), 11$ (1971)

8 Gilliland, R. B., J. Inst. Brewing, 65, 424 (1959).

9 Clark, A. G., J. Inst. Brewing, 66, 318 (1960).

10 Watson, T. G., and Hough, J, S., J. Inst. Brewing, 72, 547 (1966).

\section{Platelets and Experimental Scurvy}

HAEMORRHAGE in scurvy has been attributed to increased capillary fragility caused by reduced collagen formation ${ }^{1}$ and consequent changes in vascular endothelium and perivascular connective tissue ${ }^{2-4}$. Platelet adhesiveness to glass is impaired in human scurvy ${ }^{5-7}$ and in experimental scurvy in guineapigs $^{8,9}$. Born and Wright ${ }^{10}$ have reported a diminished velocity of adenosine diphosphate (ADP)-induced aggregation of platelets from scorbutic animals. Platelet adherence to exposed subintimal collagen, release of platelet ADP, and subsequent platelet aggregation are believed to be early events in the formation of a haemostatic plug ${ }^{11}$. These observations suggest that a platelet defect may contribute to scorbutic haemorrhage. We report here results of experiments which 